\title{
A new species of the genus Theonina Simon from Israel (Aranei: Linyphiidae)
}

\section{Новый вид рода Theonina Simon из Израимя (Aranei: Linyphiidae)}

\author{
Andrei V. Tanasevitch \\ A.B. Танасевич
}

A.N. Severtsov Institute of Ecology and Evolution, Russian Academy of Sciences, Leninsky prospekt 33, Moscow 119071, Russia. E-mail: tanasevitch@gmail.com

Институт проблем экологии и эволюции им. А.Н. Северцова РАН, Ленинский проспект 33, Москва 119071, Россия.

KEY WORDS: Taxonomy, Arachnida, spiders, Micronetinae, Middle East, Levant.

КЛЮЧЕВЫЕ СЛОВА: Таксономия, паукообразные, пауки, Мicronetinae, Ближний Восток, Левант.

ABSTRACT. A new micronetine species, Theonina canaan sp.n., is described from Israel. The species is very similar to the Mediterranean T. laguncula (Denis, 1937), but is clearly distinguished by structural details of the male palp and female epigyne.

How to cite this article: Tanasevitch A.V. 2020. A new species of the genus Theonina Simon from Israel (Aranei: Linyphiidae) // Arthropoda Selecta. Vol.29. No.3. P.367-370. doi: 10.15298/arthsel. 29.3.10

PЕЗЮМЕ. Новый вид микронетин, Theonina canaan sp.n., описан из Израиля. Вид наиболее близок к средиземноморскому T. laguncula (Denis, 1937), но хорошо отличается деталями строения пальпы самца и эпигины самки.

\section{Introduction}

The small micronetine genus Theonina Simon, 1929 is currently known to comprise four species: Theonina cornix (Simon, 1881) and T. kratochvili Miller et Weiss, 1979 in Central and Southern Europe, T. laguncula (Denis, 1937) in the Mediterranean area, and T. linyphioides (Denis, 1937) restricted to the Babor Mountains, Algeria [World Spider Catalog, 2020]. A new Theonina species has been revealed in the material from Israel collected during a short field trip in September 2011. Its description is the subject of this paper.

\section{Material and methods}

The types are kept in the Zoological Museum of the Moscow State University, Moscow, Russia (ZMMU). All specimens are preserved in $70 \%$ ethanol and have been studied using a MBS-9 stereo microscope. A Levenhuk C-800 digital camera was applied for taking some pictures. The sequence of leg segment measurements is as follows: femur + patella + tibia + metatarsus + tarsus. All measurements are given in millime- ters. The chaetotaxy is given in a formula, e.g., Ti I: 21-1-0, which means that tibia I has two dorsal spines, one pro-, one retrolateral spine, and no ventral spines (the apical spines are disregarded). Scale bars in the figures correspond to $0.1 \mathrm{~mm}$ unless indicated otherwise. Figure numbers are shown above the scale bars. The terminology concerning the structure of the copulatory organs mainly follows that of Merrett [1963] and those of the authors mentioned in the Abbreviations section below.

The following abbreviations are used in the text and figures: E - embolus, EP - embolus proper sensu Saaristo [1971], Fe - femur, LL - lateral lobes sensu Helsdingen [1965], MM — median membrane sensu Helsdingen [1965], Mt - metatarsus, PMP — posterior median plate sensu Helsdingen et al. [1977], PS - proscape sensu Saaristo \& Tanasevitch [1996], $\mathrm{R}$ - radix, St — stretcher, TA terminal apophysis sensu Helsdingen [1965], Ti — tibia, $\mathrm{TmI}$ - position of a trichobothrium on metatarsus I.

Order Aranei Clerck, 1758

Family Linyphiidae Blackwall, 1859

Subfamily Micronetinae Hull, 1920

Theonina Simon, 1929

Type species: Theonina cornix (Simon, 1881).

NOTE. Males of the known species of Theonina are characterised by the modified cymbium, the very large and thick embolus, the absence of a lamella characteristica, as well as by the complex shape of both terminal apophysis and radix. The epigyne of Theonina spp. is similar to that in some other Micronetinae genera, especially Agyneta Hull, 1911.

\section{Theonina canaan sp.n.}

Figs 1-18.

HOLOTYPE $\sigma^{7}$ (ZMMU), ISRAEL, S of Zihron Ya'aqov, environs of the Rotshild Park $\left(32.554244^{\circ} \mathrm{N} 34.942797^{\circ} \mathrm{E}\right)$, Pistacea palaestina \& Phylirea latifolia bushes, under fallen branches, 11.IX.2011, leg. A. Tanasevitch \& T. Piterkina.

PARATYPE. 1 I (ZMMU), collected together with the holotype. 


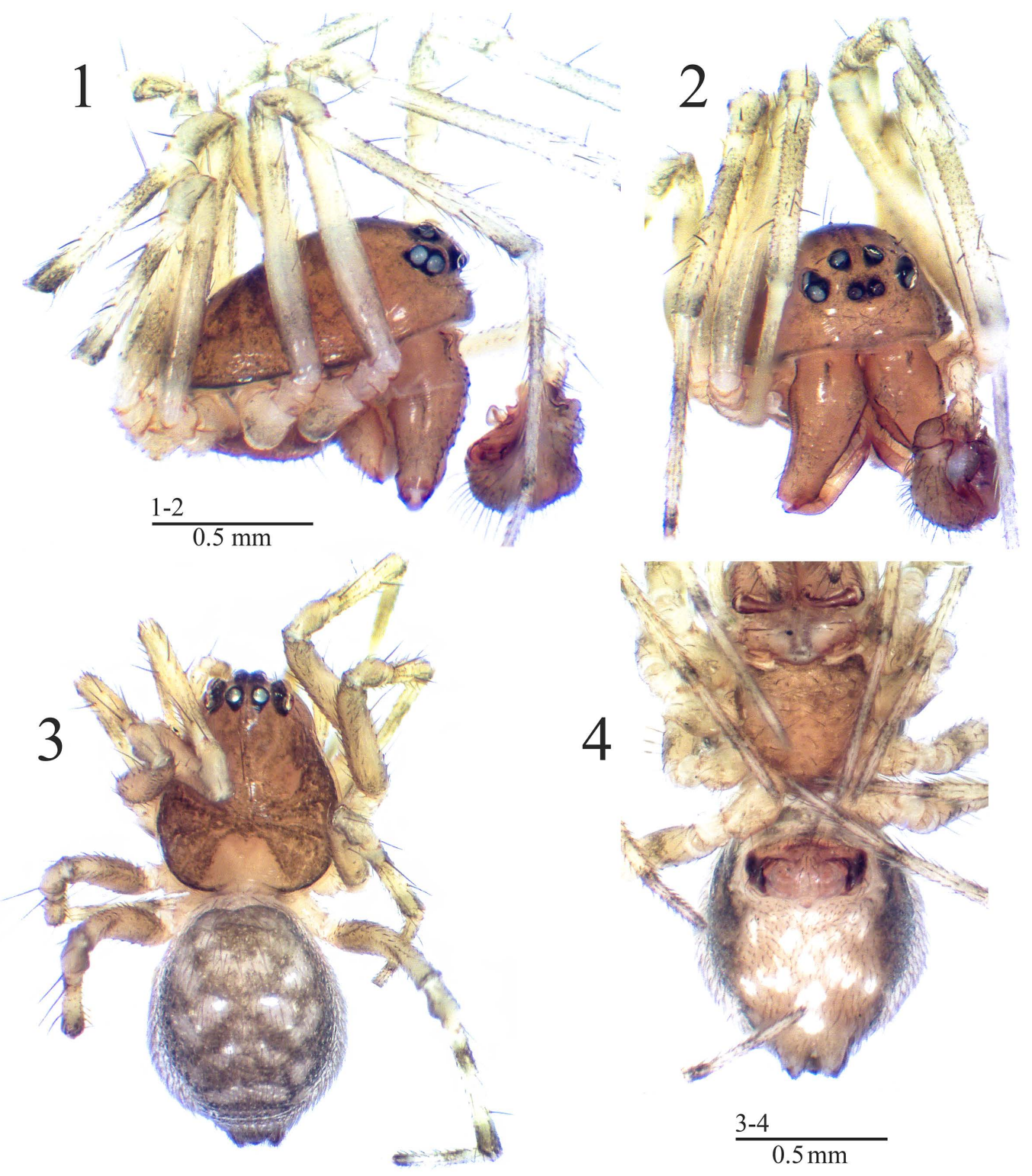

Figs 1-4. Theonina canaan sp.n., $\sigma^{7}$ holotype (1-2), o paratype (3-4). 1-2 - prosoma, lateral and frontal views, respectively; 3-4 habitus, dorsal and lateral views, respectively.

Рис. 1-4. Theonina canaan sp.n., O голотип (1-2), ๆ паратип (3-4). 1-2 - просома, вид сбоку и спереди, соответственно; 3-4 внешний вид, вид сверху и спереди, соответственно.

NAME. The species epithet is a noun in apposition, taken from the Biblic name of the "terra typica", Canaan (= Hanaan, Khanaan), part of the western Levant.

DESCRITION. Male holotype. Total length unknown, abdomen lost. Carapace (Fig. 1) slightly convex closer to cephalic part, 1.03 long, 0.80 wide, greyish-pale brown, with vague grey radial stripes and a narrow dark margin. Chelicerae large, 0.63 long, diverging distally, as shown in Fig. 2, with a small, rounded tooth at each base. Legs pale yellow, with grey bands and infuscate ends of leg segments. Leg I, 3.86 long $(1.05+0.28+1.00+0.93+0.60)$, IV , 3.19 long $(0.98+0.25+0.70+0.78+0.48)$. Chaetotaxy: FeI-IV spineless; TiI: 2-1-1-0, TiII: 2-0-1-0, TiIII-IV: 2-0-0-0; MtIIII: $1-0-0-0$, MtIV spineless. Spines $1.5-2.5 \mathrm{x}$ as long as diameter of corresponding leg segment. TmI 0.19. Metatarsi IV without trichobothria. Palp (Figs 5-16): Patella dorsally with a knob terminating in a spine. Tibia with a flat and rounded outgrowth apically. Cymbium bearing two small knob-shaped extensions postero-dorsally. Paracymbium large, flat, with a row of long spines in its distal part. Distal suprategular apophysis bifid. Radix complex, with several apophyses. Terminal apophysis consisting of two parts: TA1 and TA2, as shown in Figs 5, 13-14. Embolus very large, thick, slightly curved, embolus proper bifid, a thumb absent. Abdomen lost.

Female. Total 1.70 length. Carapace 0.78 long, 0.65 wide. Chelicerae $0.35 \mathrm{long}$, unmodified, a special tooth at base absent. Leg I, 2.93 long $(0.80+0.23+0.70+0.70+$ 


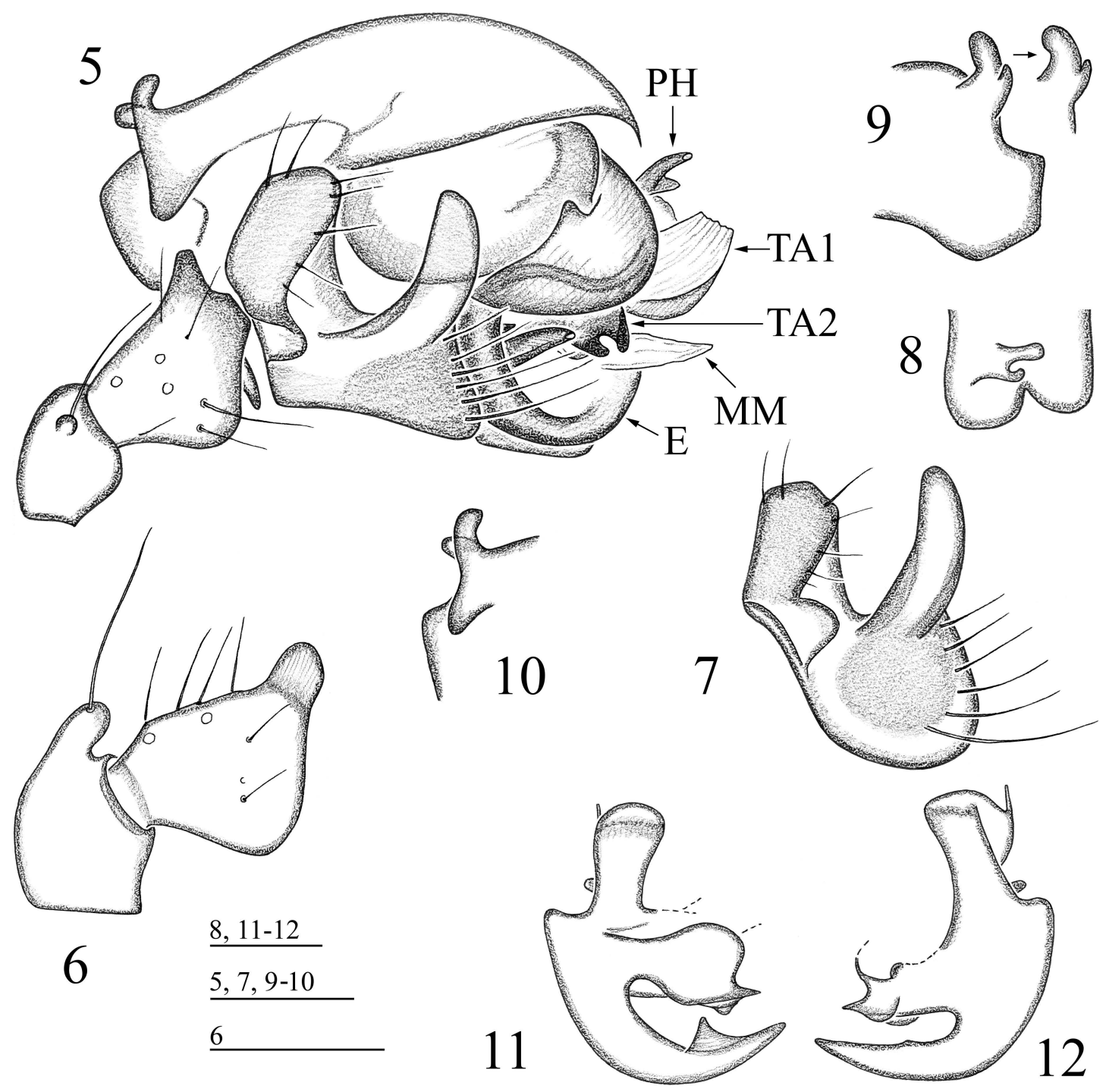

Figs 5-12. Details of male palpal structure of Theonina canaan sp.n., $\sigma^{7}$ holotype. 5 - right palp, retrolateral view; 6 - patella and palpal tibia, retrolateral view; 7 - paracymbium; $8-10$ - proximal part of cymbium, dorsal, prolateral and retrolateral views, respectively; $11-12$ - radix, different aspects.

Рис. 5-12. Детали строения пальпы самца Theonina canaan sp.n., о7 голотип. 5 - правая пальпа, ретролатерально; 6 - колено и голень пальпы, ретролатерально; 7 - парацимбиум; 8-10- проксимальный отдел цимбиума, вид сверху, спереди и сзади, соответственно; 11-12 - радикс, различные аспекты.

$0.50)$, IV, 2.76 long $(0.85+0.25+0.60+0.63+0.43)$. TmI 0.23. Abdomen 0.93 long, 0.65 wide, dorsal pattern as shown in Fig. 3. Epigyne (Figs 17-18): Lateral sides of proscape almost parallel, distal part of proscape with a shallow hollow apically. Lateral lobes expanded, covering almost all epigynal cavity. Stretcher short. Posterior median plate complex in shape, as shown in Fig. 18. Carapace and leg colouration, chaetotaxy as in male.

TAXONOMIC REMARKS. The species is very similar to the Mediterranean $T$. laguncula, hitherto known from Morocco, Spain, Algeria and Cyprus [Bosmans et al., 2019]. The male of the new species distinctly differs by the presence of a basal cheliceral tooth, of two small knob-shaped postero-dorsal extensions on the cymbium (see Figs 5, 8-
10), the shapes of the radical apophyses (Figs 11-13 cf. fig. $13 \mathrm{f}$ in Bosmans et al., 2019), as well as by the structure of the terminal apophysis. The epigyne of both species are likewise very similar, but they can be distinguished by the shape of the posterior median plate (Fig. $18 \mathrm{cf}$. fig. 13k in Bosmans et al., 2019).

DISTRIBUTION. Known only from the type locality near Zihron Ya'aqov in Israel.

Acknowledgements. I am most grateful to Sergei Golovatch (Moscow) for editing an advanced draft of the manuscript.

This study was supported in part by the Presidium of the Russian Academy of Sciences, Program No. 41 "Biodiversity of natural systems and biological resources of Russia". 

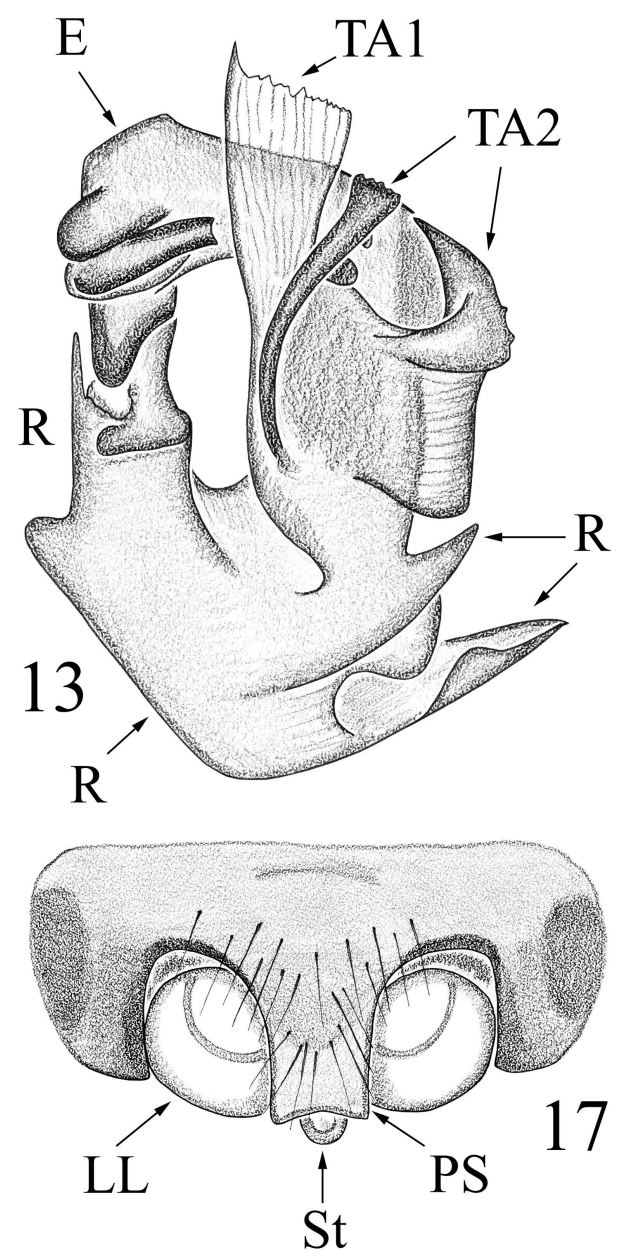
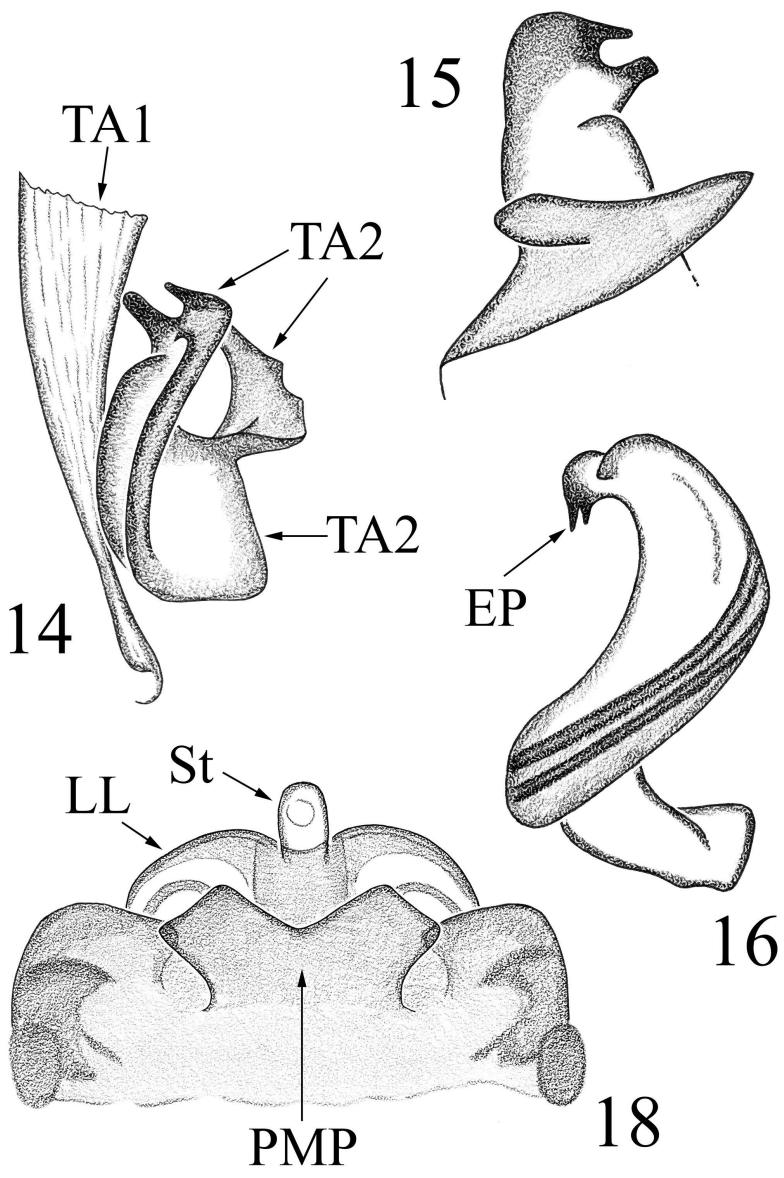

$\underline{17-18}$

$13-14,16$

$\underline{15}$

Figs 13-18. Details of male palpal and epigynal structure of Theonina canaan sp.n., ơ holotype (13-16), † paratype (17-18). $13-$ embolic division; 14 - terminal apophysis (TA1 and TA2); 15 - distal part of left branch of TA2; 16 - embolus; 17-18 - epigyne, ventral and dorsal views, respectively.

Рис. 13-18. Детали строения пальпы самца и эпигины самки Theonina canaan sp.n., о7 голотип (13-16), 9 паратип (17-18). 13 эмболюсный отдел; 14 - терминальная апофиза (ТА1 и ТА2); 15 — дистальный отдел левой ветви ТА2; 16 — эмболюс; 17-18 — эпигина, вид снизу и сверху, соответственно.

\section{References}

Bosmans R., Van Keer J., Russell-Smith A., Hadjiconstantis M., Komnenov M., Bosselaers J., Huber S., McCowan D., Snazell R., Decae A., Zoumides C., Kielhorn K.-H., Oger P. 2019. Spiders of Cyprus (Araneae). A catalogue of all currently known species from Cyprus // Newsletter of the Belgian Arachnological Society. Vol.34 (Supplement). P.1-173.

Helsdingen P.J., van 1965. Sexual behaviour of Lepthyphantes leprosus (Ohlert) (Araneida, Linyphiidae), with notes on the function of the genital organs // Zoologische Mededelingen. Vol.41. P.15-42.

Helsdingen P.J., van, Thaler K., Deltshev C. 1977. The tenuis group of Lepthyphantes Menge (Araneae, Linyphiidae) // Tijdschrift voor Entomologie. Vol.120. P.1-54.
Merrett P. 1963. The palpus of male spiders of the family Linyphiidae // Proceedings of the Zoological Society of London. Vol.140. P.347-467.

Saaristo M.I. 1971. Revision of the genus Maro O. P.-Cambridge (Araneae, Linyphiidae) // Annales Zoologici Fennici. Vol.8. P.463-482.

Saaristo M.I., Tanasevitch A.V. 1996. Redelimitation of the subfamily Micronetinae Hull, 1920 and the genus Lepthyphantes Menge, 1866 with descriptions of some new genera // Berichte des Naturwissenschaftlich-Medizinischen Vereins in Innsbruck. Bd.83. S.163-186.

World Spider Catalog 2020. World Spider Catalog, version 21.0. Natural History Museum Bern. Available at http://wsc.nmbe.ch (accessed in June 2020).

Responsible editor K.G. Mikhailov 